\title{
Hirsutanol A inhibits T-acute lymphocytic leukemia Jurkat cell viability through cell cycle arrest and p53-dependent induction of apoptosis
}

\author{
FANGFANG ZHONG ${ }^{1,2}$, YOU YANG ${ }^{1,2}$, DANWEI REN ${ }^{2}$, SILI LONG ${ }^{2}$, XIANG QIN $^{1,2}$,

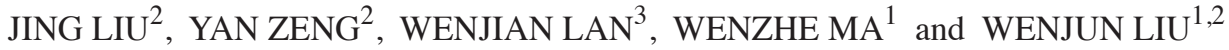 \\ ${ }^{1}$ State Key Laboratory of Quality Research in Chinese Medicine, Macau University of Science and Technology, \\ Macau 999078, Macau SAR; ${ }^{2}$ Department of Pediatrics, Affiliated Hospital of Southwest Medical University, \\ Sichuan Clinical Research Center for Birth Defects, Luzhou, Sichuan 646000; ${ }^{3}$ School of Pharmaceutical Sciences, \\ Sun Yat-sen University, Guangzhou, Guangdong 510006, P.R. China
}

Received January 21, 2020; Accepted April 21, 2021

DOI: $10.3892 /$ etm.2021.10173

\begin{abstract}
Acute lymphocytic leukemia (ALL) is a type of childhood leukemia with the highest incidence; T-acute lymphocytic leukemia (T-ALL) is far more difficult to treat than B-acute lymphocytic leukemia (B-ALL) and has a poor long-term prognosis. Therefore, there is an urgent requirement to develop effective drugs for the treatment of T-ALL. Hirsutanol A is a natural sesquiterpenoid compound. The aim of the present study was to evaluate the in vitro anticancer activity of hirsutanol A against T-acute lymphocytic leukemia Jurkat cells and investigate the mechanism of action. A Cell Counting Kit- 8 assay demonstrated that hirsutanol A inhibited the viability of Jurkat cells in a dose- and time-dependent manner. In addition, hirsutanol A induced cell cycle arrest at the $\mathrm{G}_{2}$ phase as determined via flow cytometry. Furthermore, Hoechst staining, Annexin V-FITC/propidium iodide double staining, mitochondrial membrane potential detection using JC-1 and western blot analysis of apoptotic proteins indicated that the inhibitory effect of hirsutanol A on Jurkat cells was associated with the induction of apoptosis. Of note, hirsutanol A induced the expression of the tumor suppressor p53, whereas simultaneous treatment with pifithrin- $\alpha$, an inhibitor
\end{abstract}

Correspondence to: Professor Wenzhe Ma, State Key Laboratory of Quality Research in Chinese Medicine, Macau University of Science and Technology, Avenida Wai Long, Taipa, Macau 999078, Macau SAR, P.R. China

E-mail:wzma@must.edu.mo

Professor Wenjun Liu, Department of Pediatrics, Affiliated Hospital of Southwest Medical University, Sichuan Clinical Research Center for Birth Defects, 25 Taiping Street, Jiangyang, Luzhou, Sichuan 646000, P.R. China

E-mail: lwjlyfy@qq.com

Key words: hirsutanol A, apoptosis, T-acute lymphocytic leukemia, p53 of p53, significantly reduced Jurkat cell apoptosis induced by hirsutanol A. In summary, the present study suggested that hirsutanol A inhibited Jurkat cell viability through induction of cell cycle arrest and p53-dependent initiation of apoptosis, thus hirsutanol may serve as a promising compound for the treatment of T-ALL.

\section{Introduction}

Leukemia is the most common type of childhood malignancy worldwide (1). Every year, >10,000 new cases of acute lymphocytic leukemia (ALL) in children occur in China, and T-ALL accounts for $15 \%$ of them (2-5). T-ALL is caused by the diffuse bone marrow infiltration of immature $\mathrm{T}$ lymphoblasts, which clinically manifests as central nervous system infiltration and mediastinal mass with pleural effusion in the early stage (6). T-ALL is far more difficult to treat than B-ALL and has a poor long-term prognosis $(7,8)$ resulting from poor sensitivity and resistance to chemotherapeutic drugs, issues with remission and clearance of bone marrow microresidual lesions, and a high recurrence rate in the central nervous system $(9,10)$. With the advancement of chemotherapy regimens, the 5-year disease-free survival rate of pediatric T-ALL has substantially improved (11-13). However, the adverse effects of the high-intensity chemotherapy regimen are unfavorable, including liver and kidney damage, as well as severe infections secondary to bone marrow suppression $(14,15)$. Hematopoietic stem cell transplantation may maximize the treatment efficiency of refractory ALL, but due to the shortage of donor sources and low degree of matching, as well as insufficient economic resources, its benefit is limited in the majority of cases of pediatric T-ALL $(16,17)$. Therefore, there is an urgent requirement to discover novel therapeutic targets and develop drugs for the treatment of T-ALL.

By screening a natural compound library owned by State Key Laboratory of Quality Research in Chinese Medicine (Macau, China), it was revealed that hirsutanol A exerted a clear inhibitory effect on the viability of the T-ALL cell line Jurkat. Hirsutanol A is a sesquiterpenoid compound initially 
isolated from an unidentified fungus isolated from the Indo-Pacific sponge Haliclona sp. with antitumor, antibacterial and antioxidant activities (18). The chemical structure of hirsutanol A is presented in Fig. 1 (18). Subsequent studies have indicated that hirsutanol A potently inhibits the proliferation of a variety of tumor cells by increasing the level of reactive oxygen species, and inducing apoptosis and autophagy $(19,20)$. However, these studies were focused on solid tumor cells, including liver and breast cancer, and to the best of our knowledge, the antileukemia activities of hirsutanol A have not been previously assessed.

The aim of the present study was to evaluate the in vitro anticancer activity of hirsutanol A against T-acute lymphocytic leukemia Jurkat cells by Cell Counting Kit- 8 assay, western blot analysis and other related biological techniques, and to explore the mechanism of action. It is hoped to lay the experimental foundation for finding a new drug to treat T-ALL.

\section{Materials and methods}

Cell lines and culture. The human T-ALL cell line Jurkat and the human T-lymphoid cell line H9 were purchased from the American Type Culture Collection. Cells were cultured in complete medium containing 90\% RPMI-1640 (HyClone; Cytiva) and 10\% FBS (Hangzhou Sijiqing Biological Engineering Materials Co., Ltd.) with $1 \%$ penicillin-streptomycin mixture (Beijing Solarbio Science \& Technology Co., Ltd.) in an incubator with $5 \% \mathrm{CO}_{2}$ and saturated humidity at $37^{\circ} \mathrm{C}$.

Reagents. Hirsutanol A, a sesquiterpenoid compound isolated and synthesized in the laboratory of Professor Lan Wenjian, School of Pharmacy, Sun Yat-sen University, China, was dissolved in DMSO and stored in a refrigerator at $-40^{\circ} \mathrm{C}$ until use.p53 inhibitor pifithrin- $\alpha$ (PFT $\alpha)$ was purchased from APeXBIO Technology LLC. The Cell Counting Kit-8 (CCK-8) was purchased from Dojindo Molecular Technologies Inc. Hoechst 33258 was purchased from Beijing Solarbio Science \& Technology Co., Ltd. An apoptosis test kit (Annexin V-FITC Apoptosis Detection Kit I) was purchased from BD Biosciences, and the cell cycle detection kit was purchased from Nanjing KeyGen Biotech Co., Ltd. Rabbit anti-human p53 (1:1,000; cat. no. 2527), p53 upregulated modulator of apoptosis (Puma; 1:1,000; cat. no. 12450), Bcl-2 (1:1,000; cat. no. 4223), Caspase-3 (1:1,000; cat. no. 9662), poly (ADP-ribose) polymerase (PARP; 1:1,000; cat. no. 9532), cleaved caspase-3 (cCaspase-3; 1:1,000; cat. no. 9664) and cleaved poly(ADP-ribose) polymerase (cPARP; 1:1,000; cat. no. 9185) monoclonal antibodies were purchased from Cell Signaling Technology, Inc. The rabbit anti-human GAPDH $(1: 1,000$; cat. no. 10494-1-AP) primary antibody was purchased from ProteinTech Group, Inc. The horseradish peroxidase-labeled goat anti-rabbit secondary antibody (1:1,000; cat. no. A0208) was purchased from Shanghai Beyotime Biotechnology Co., Ltd.

Cell viability assay. Jurkat cells were collected and resuspended in medium to adjust the cell density to $2 \times 10^{5}$ cells $/ \mathrm{ml}$. This cell suspension was added to a $96-$ well plate at $90 \mu \mathrm{l} /$ well. Subsequently, hirsutanol A (10 $\mu \mathrm{l} /$ well) at different concentrations $(0.71,1.42,2.84,5.68$ and $11.36 \mu \mathrm{M})$ was added for incubation. In parallel, a blank group and a control group (containing only cells and culture medium) were used, and each group was set up in 3 duplicate wells. Following incubation for $48 \mathrm{~h}, 5 \mu \mathrm{l}$ CCK-8 solution was added to each well, followed by incubation for another $4 \mathrm{~h}$. The optical density (OD) value of each well was measured using an ultraviolet spectrophotometer (Beckman Coulter, Inc.) at a wavelength of $450 \mathrm{~nm}$. Human $\mathrm{T}$ lymphocyte $\mathrm{H} 9$ cells were treated with a series of hirsutanol A concentrations $(2,4,8,16$, and $32 \mu \mathrm{M})$ for $48 \mathrm{~h}$, and the other experimental procedures were the same as Jurkat cells. In addition, Jurkat cells were treated with $5 \mu \mathrm{M}$ hirsutanol $\mathrm{A}$, and viability was assessed at different time points $(24,48$, and $72 \mathrm{~h})$ after treatment. The cell viability rate was calculated as follows: Cell viability rate $(\%)=(\mathrm{OD}$ value of the experimental group - OD value of the blank group) / (OD value of the control group - OD value of the blank group). The half-maximal inhibitory concentration $\left(\mathrm{IC}_{50}\right)$ of hirsutanol $\mathrm{A}$ was determined as the concentration of the drug leading to $50 \%$ cell inhibition.

Apoptosis assay. Cell apoptosis was assessed using the Annexin V-FITC Apoptosis Detection Kit I. Jurkat cells were collected and resuspended to adjust the cell density to $2 \times 10^{5}$ cells $/ \mathrm{ml}$. This cell suspension was added to a 6 -well plate at $2 \mathrm{ml} /$ well and different concentrations $(0,3,5,6$, and $9 \mu \mathrm{M})$ of hirsutanol A and/or PFT $\alpha(10 \mu \mathrm{M})$ were added. After $48 \mathrm{~h}$ of incubation at $37^{\circ} \mathrm{C}$, the cells were collected, washed twice with cold PBS and resuspended with $1 \mathrm{X}$ binding buffer. Of this suspension, $100 \mu 1\left(\sim 1 \times 10^{5}\right.$ cells $\left./ \mathrm{ml}\right)$ were placed in a 5-ml culture tube and propidium iodide (PI; $5 \mu \mathrm{l})$ and Annexin V-FITC (5 $\mu \mathrm{l})$ were added. Following incubation for $15 \mathrm{~min}$ in the dark at room temperature, $200 \mu \mathrm{l} 1 \mathrm{X}$ binding buffer was added per tube and apoptotic cells were detected using a BD FACScan ${ }^{\mathrm{TM}}$ flow cytometer (BD Biosciences) within $1 \mathrm{~h}$. The results were analyzed using BD FACSuite ${ }^{\mathrm{TM}}$ (BD Biosciences). Early and late apoptosis were assessed.

Cell cycle analysis. The cell cycle was assessed using the cell cycle detection kit. Jurkat cells were collected and resuspended to adjust the cell density to $2 \times 10^{5}$ cells $/ \mathrm{ml}$. This cell suspension was added to a 6 -well plate at $2 \mathrm{ml} /$ well and different concentrations $(0,3,5,6$, and $9 \mu \mathrm{M})$ of hirsutanol A and/or PFT $\alpha$ $(10 \mu \mathrm{M})$ were added. After $48 \mathrm{~h}$ of incubation, the cells were collected, washed with PBS and fixed with $70 \%$ cold ethanol at $4^{\circ} \mathrm{C}$ overnight. Following centrifugation $\left(300 \mathrm{x}\right.$ g at $4^{\circ} \mathrm{C}$ and $5 \mathrm{~min}$ ) and washing with PBS, $400 \mu \mathrm{l} \mathrm{PI/RNase} \mathrm{A} \mathrm{staining}$ solution (PI/RNase A ratio, 1:9; prepared in advance) was added, followed by incubation at room temperature in the dark for $30 \mathrm{~min}$. Subsequently, the cell cycle was assessed using a BD FACScan ${ }^{\mathrm{TM}}$ flow cytometer. The results were analyzed using ModFit LT 4.0 (Verity Software House, Inc.).

Hoechst 33258 staining assay. Jurkat cells were collected and resuspended to adjust the cell density to $2 \times 10^{5}$ cells $/ \mathrm{ml}$. The suspension was added to a 6 -well plate at $2 \mathrm{ml} /$ well. Following the addition of different concentrations $(0,3,6$, and $9 \mu \mathrm{M})$ of hirsutanol A, the cells were incubated for $48 \mathrm{~h}$. Subsequently, the cells were collected, Hoechst 33258 working solution $(5 \mu \mathrm{g} / \mathrm{ml})$ was added to fully cover the cells and the cells were then placed in an incubator at $37^{\circ} \mathrm{C}$ for $30 \mathrm{~min}$. The staining solution was discarded via centrifugation $(300 \mathrm{x} \mathrm{g}$ at room 


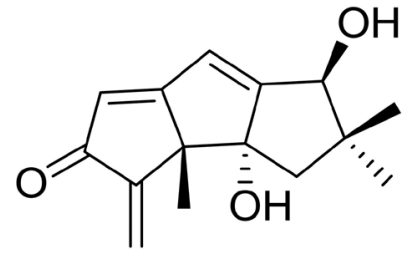

Figure 1. Chemical structure of hirsutanol A.

temperature for $5 \mathrm{~min}$ ) and the cells were washed with PBS twice, followed by observation via fluorescence microscopy (maximum excitation wavelength, $352 \mathrm{~mm}$; maximum emission wavelength, $461 \mathrm{~mm}$ ). Each sample was viewed from five fields with roughly the same number of cells.

Mitochondrial membrane potential detection. JC-1 buffer (1X) was prepared from 5X JC-1 buffer (Beijing Solarbio Science \& Technology Co., Ltd) and distilled water at a ratio of 1:4 and maintained in an ice bath for later use. Jurkat cells were collected and resuspended to adjust the cell density to $2 \times 10^{5}$ cells $/ \mathrm{ml}$. This cell suspension was transferred to a 6 -well plate at $2 \mathrm{ml} /$ well and the cells were treated with different concentrations $(0,3,6$, and $9 \mu \mathrm{M})$ of hirsutanol $\mathrm{A}$ for $48 \mathrm{~h}$. The cells were then collected and resuspended in medium, JC-1 staining solution was added and then the suspension was inverted several times to mix. The cells were cultured in the incubator at $37^{\circ} \mathrm{C}$ for $30 \mathrm{~min}$. Following centrifugation $\left(300 \mathrm{x} \mathrm{g}\right.$ at $4^{\circ} \mathrm{C}$ and $5 \mathrm{~min}$ ), the supernatant was discarded and the cells were washed twice with JC-1 buffer $(1 \mathrm{X})$. The cells were then observed under a fluorescence microscope. Each sample was viewed from five fields with roughly the same number of cells.

Western blot analysis. Jurkat cells treated with different concentrations $(0,3,5$ and $6 \mu \mathrm{M})$ of hirsutanol A and/or PFT $\alpha(10 \mu \mathrm{M})$ were collected and washed twice with PBS. Then, lysis buffer (80:10:10:1 ratio of RIPA lysate (Beyotime Institute of Biotechnology), protease inhibitor, phosphatase inhibitor and PMSF) was added, and cells were lysed on ice for $30 \mathrm{~min}$. Following centrifugation at 4,000 x g for $10 \mathrm{~min}$ at $4^{\circ} \mathrm{C}$, the supernatant was obtained and the protein concentration was measured via the bicinchoninic acid method. The supernatant was mixed with SDS-PAGE protein loading buffer $(5 \mathrm{X})$ and the mixture was placed in a metal bath at $100^{\circ} \mathrm{C}$ for $5 \mathrm{~min}$ to denature the protein. Protein samples (20 $\mu \mathrm{g} /$ lane) were separated via 10\% SDS-PAGE (the current and time were appropriately adjusted according to different proteins), followed by transfer onto Immobilon ${ }^{\circledR}$ polyvinylidene difluoride membranes (Sigma-Aldrich; Merck KGaA) and blocking with 5\% skimmed milk at room temperature for $1 \mathrm{~h}$. The membrane was incubated with the aforementioned primary antibodies at $4^{\circ} \mathrm{C}$ overnight and then incubated with a secondary antibody for $1 \mathrm{~h}$ at room temperature. The bands were visualized using an enhanced chemiluminescence kit (EMD Millipore) and images were captured on a chemiluminescence imager (Vilber Lourmat). GAPDH was used as the loading control. Protein expression was semi-quantified using ImageJ version 2.0 software (National Institutes of Health).
Statistical analysis. The data were analyzed with SPSS 19.0 software (SPSS, Inc.) and expressed as the mean \pm standard deviation of at least three independent experiments. Differences between two groups were assessed using the paired Student's t-test. Differences amongst multiple groups were evaluated using one-way ANOVA followed by Tukey's post hoc test. $\mathrm{P}<0.05$ was considered to indicate a statistically significant difference.

\section{Results}

Hirsutanol A inhibits the viability of Jurkat cells. The antiproliferative effect of hirsutanol A on the T-ALL cell line Jurkat was examined using a CCK-8 assay. Jurkat cells were treated with a series of hirsutanol A concentrations from 0.71 to $11.44 \mu \mathrm{M}$ for $48 \mathrm{~h}$. As presented in Fig. 2A, hirsutanol A markedly reduced the viability of Jurkat cells in a concentration-dependent manner, with an $\mathrm{IC}_{50}$ value of $5.16 \mu \mathrm{M}$. Therefore, three concentrations $(3,6$ and $9 \mu \mathrm{M})$ were selected in the subsequent experiments. Furthermore, human T lymphocyte H9 cells were treated with a series of hirsutanol A concentrations from 2 to $32 \mu \mathrm{M}$ for $48 \mathrm{~h}$, displaying an $\mathrm{IC}_{50}$ value of $16.22 \mu \mathrm{M}$ (Fig. $2 \mathrm{C}$ ). These results indicated that hirsutanol A was less toxic to the normal cell line compared with the T-ALL cell line. Consistent with the dose effect of hirsutanol A, the viability of Jurkat cells was also inhibited in a time-dependent manner. Jurkat cells were then treated with $5 \mu \mathrm{M}$ hirsutanol $\mathrm{A}$, and cytotoxicity was assessed at different time points after treatment. At $24 \mathrm{~h}$, the cell viability rate of Jurkat cells was $89.24 \pm 2.58 \%$, which declined to $21.83 \pm 0.61 \%$ at $72 \mathrm{~h}$ (Fig. 2B). Thus, these results indicated that hirsutanol A inhibited the viability of T-ALL Jurkat cells in a dose- and time-dependent manner.

Hirsutanol A inhibits cell cycle progression in Jurkat cells. It is well known that cell cycle arrest is a key intracellular event contributing to reduced cell proliferation (21). It was therefore assessed whether hirsutanol A altered the cell cycle progression of Jurkat cells via flow cytometric analysis. As presented in Fig. 3, after $48 \mathrm{~h}$ of hirsutanol A treatment, the population of Jurkat cells in the $\mathrm{G}_{2}$ phase increased significantly, whereas there was no significant change in the proportion of cells in the $\mathrm{S}$ phase compared with the control group, suggesting that hirsutanol A blocked the cell cycle of Jurkat cells in the $\mathrm{G}_{2}$ phase.

Hirsutanol A induces apoptosis in Jurkat cells. To further clarify whether the inhibitory effect of hirsutanol A on Jurkat cell viability resulted from the induction of apoptosis, Jurkat cells were treated with a series of concentrations of the compound for $48 \mathrm{~h}$, stained with Hoechst 33258 and then visualized under a fluorescence microscope. As presented in Fig. 4A, with increasing hirsutanol A concentrations, Jurkat cells exhibited typical morphological characteristics of apoptosis, including nuclear fragmentation and chromatin condensation. The induction of apoptosis was further demonstrated via flow cytometric analysis of cells stained with Annexin V-FITC/PI. The results indicated that, compared with the control group, hirsutanol A significantly induced the apoptosis of Jurkat cells in a dose-dependent manner (Fig. 4B and C). The percentages 
A

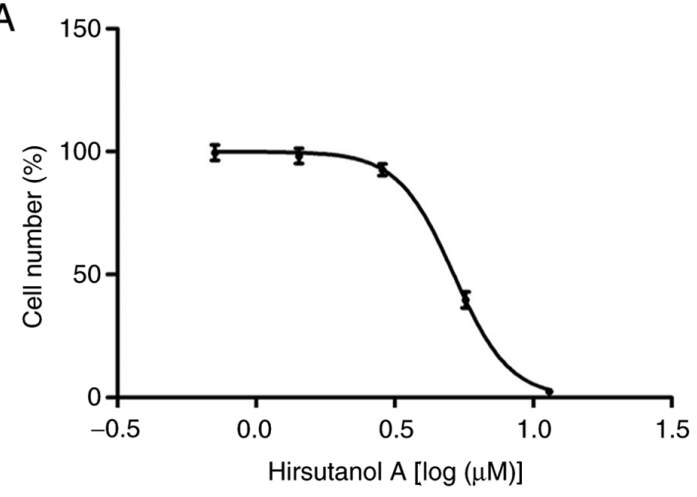

B

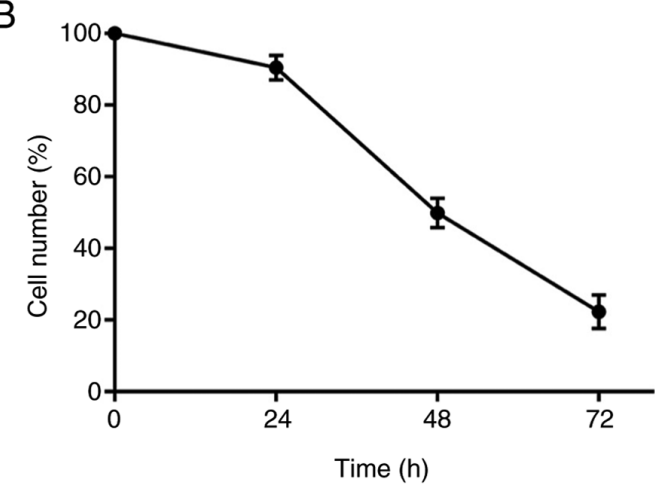

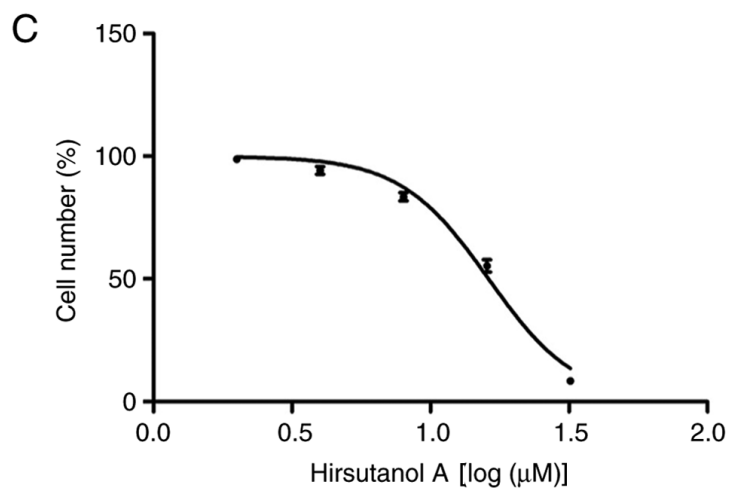

Figure 2. Hirsutanol A inhibits the viability of Jurkat cells. (A) Dose effect of hirsutanol A treatment for $48 \mathrm{~h}$ and (B) time course of the effect of hirsutanol A treatment $(5 \mu \mathrm{M})$ on the viability of Jurkat cells. (C) Dose effect of hirsutanol A treatment for $48 \mathrm{~h}$ on the viability of $\mathrm{H} 9$ cells. The cell number at each dose or time point is presented as the percentage of the control. Data are presented as the mean \pm standard deviation of three independent experiments.
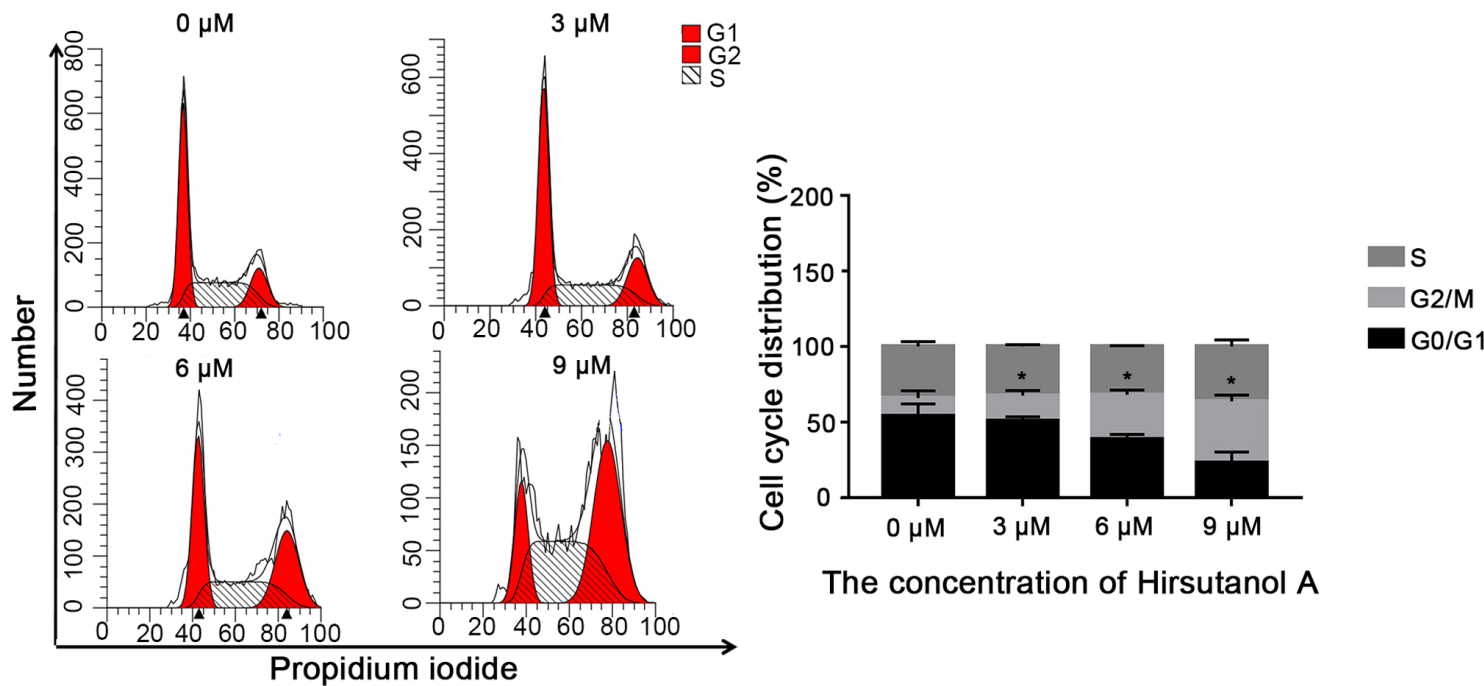

Figure 3. Hirsutanol A induces cell cycle arrest in Jurkat cells. After treatment with hirsutanol A at indicated concentrations for $48 \mathrm{~h}$, cell cycle distributions of Jurkat cells were analyzed via flow cytometry. Data are presented as the mean \pm standard deviation of three independent experiments. " $\mathrm{P}<0.05$ vs. $0 \mu \mathrm{M}$.

of total apoptotic cells following hirsutanol A treatment for $48 \mathrm{~h}$ were $15.94 \pm 0.33 \%$ at $3 \mu \mathrm{M}, 47.53 \pm 0.74 \%$ at $6 \mu \mathrm{M}$ and $81.25 \pm 1.42 \%$ at $9 \mu \mathrm{M}$, compared with $5.72 \pm 0.31 \%$ in the control group.

The mitochondrial pathway is one of the most classical pathways of cell apoptosis (22). In the early stage of cell apoptosis, the mitochondrial structure undergoes certain crucial changes, one of which is loss of the mitochondrial membrane potential $(23,24)$. Therefore, in the present study, changes in the mitochondrial membrane potential of Jurkat cells after $48 \mathrm{~h}$ of hirsutanol A treatment at different concentrations were detected via JC-1 staining. As presented in Fig. 4D, the green fluorescence was markedly increased in a hirsutanol A dose-dependent manner, indicating that cells lost their mitochondrial membrane potential following hirsutanol A treatment. 
A
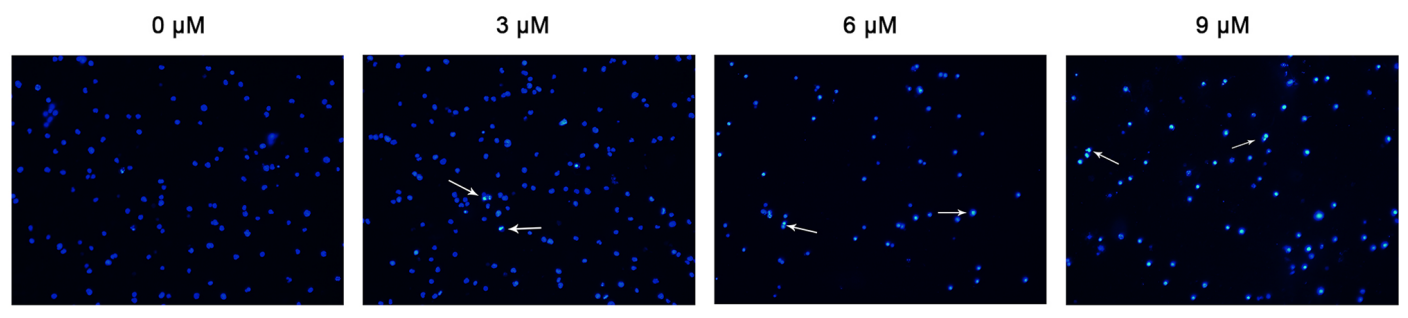

B

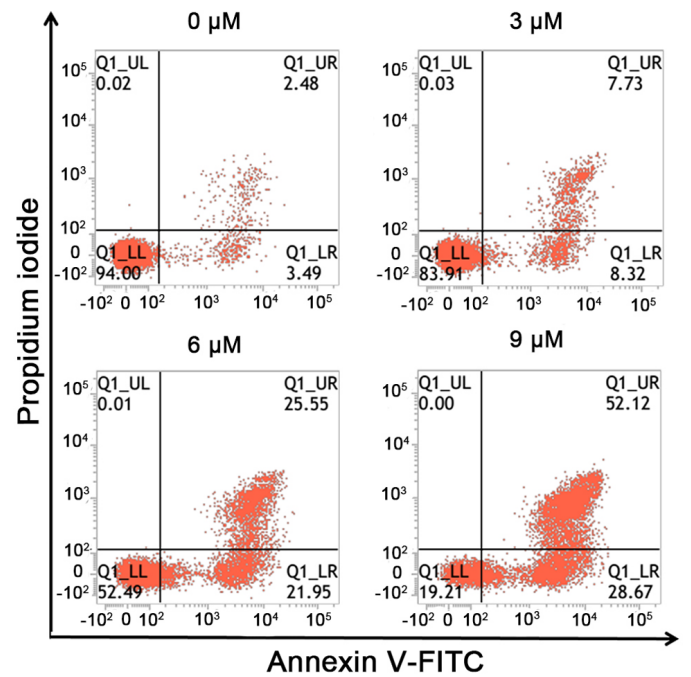

C

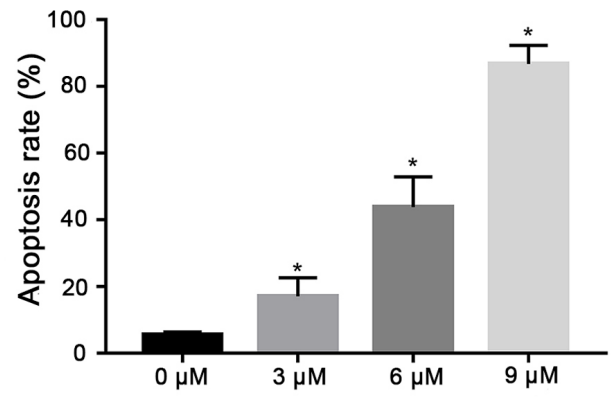

The concentration of Hirsutanol A

D

$0 \mu \mathrm{M}$

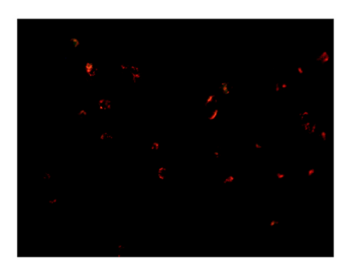

$3 \mu \mathrm{M}$

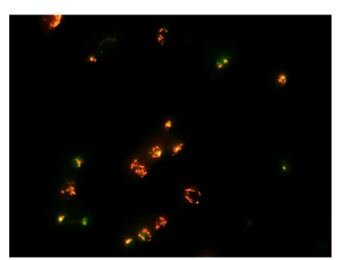

$6 \mu \mathrm{M}$

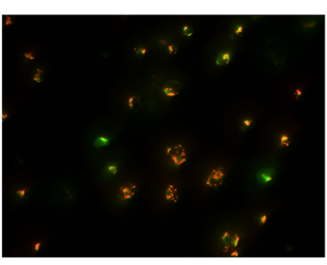

$.9 \mu \mathrm{M}$

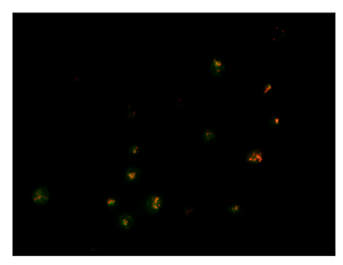

E

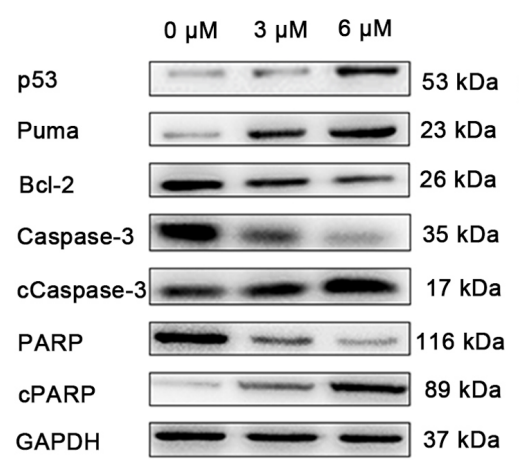

F
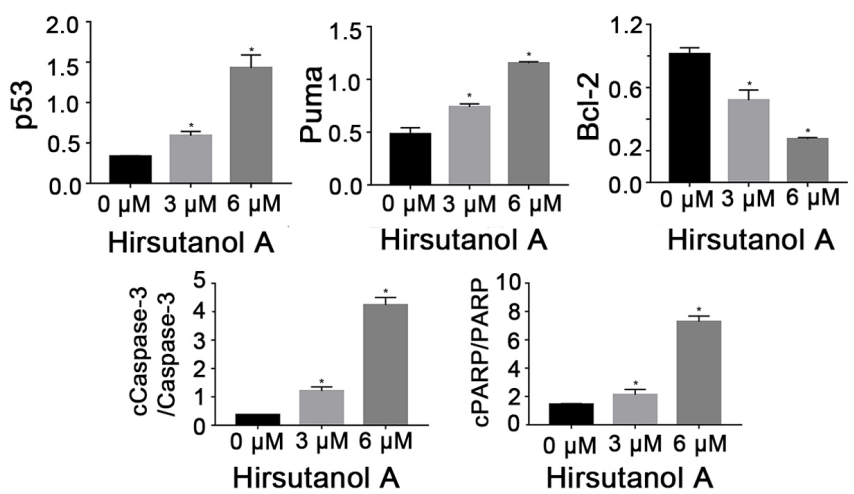

Figure 4. Hirsutanol A induces apoptosis in Jurkat cells. Jurkat cells were treated with hirsutanol A at indicated concentrations for $48 \mathrm{~h}$. (A) Visualization of apoptotic morphological changes using a fluorescent microscope following Hoechst 33258 staining. Representative images are provided and apoptotic cells are indicated by arrows (magnification, x200). (B) Representative dot plots of the flow cytometric analysis of apoptosis. (C) Fractions of apoptotic cells were quantified. (D) Changes in mitochondrial membrane potential were detected using JC-1 (magnification, x400). The decreased red/green fluorescence ratio with hirsutanol A treatment indicated mitochondrial depolarization and early stages of apoptosis in Jurkat cells. With increasing concentrations, the level of green fluorescence, representing the early stage of apoptosis, increased. (E) Western blot analysis of apoptosis- and survival-associated proteins. (F) Semi-quantification of p53, Puma, Bcl-2, cCaspase- 3 and cPARP protein expression levels. ${ }^{*} \mathrm{P}<0.05 \mathrm{vs} .0 \mu \mathrm{M}$. Data are presented as the mean \pm standard deviation of three independent experiments. c, cleaved; PARP, poly(ADP-ribose) polymerase; Puma, p53 upregulated modulator of apoptosis. 
A

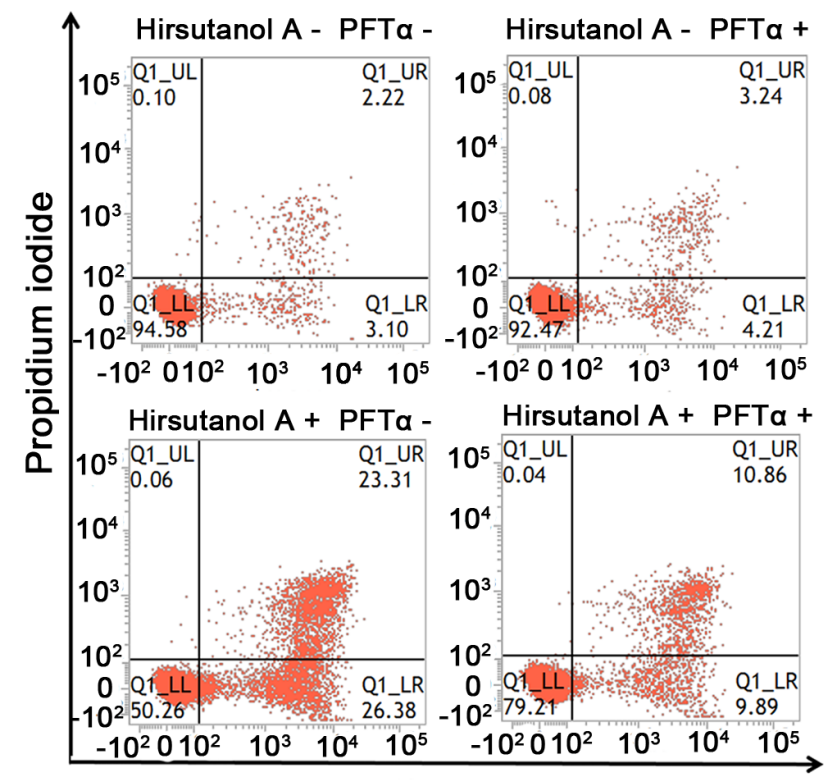

B

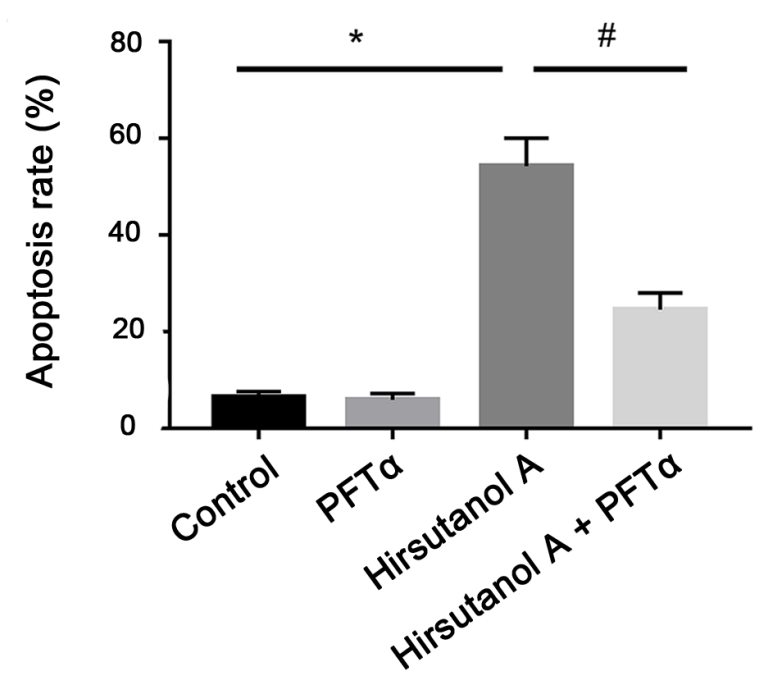

C

Annexin V-FITC

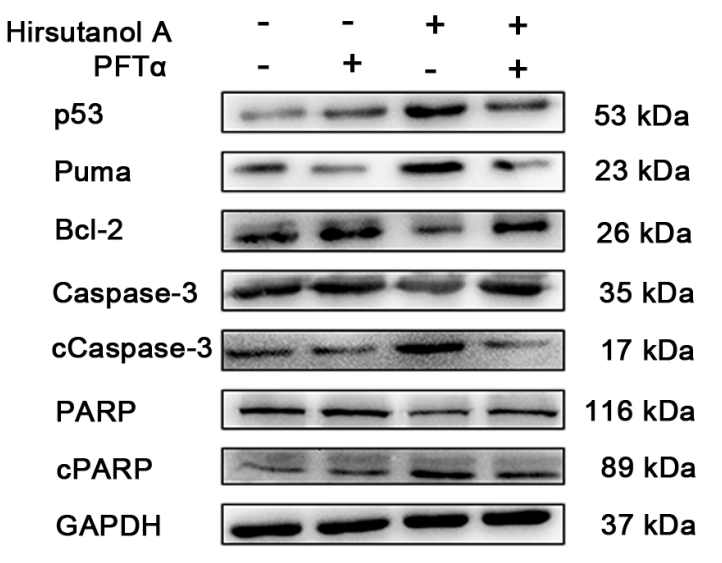

D
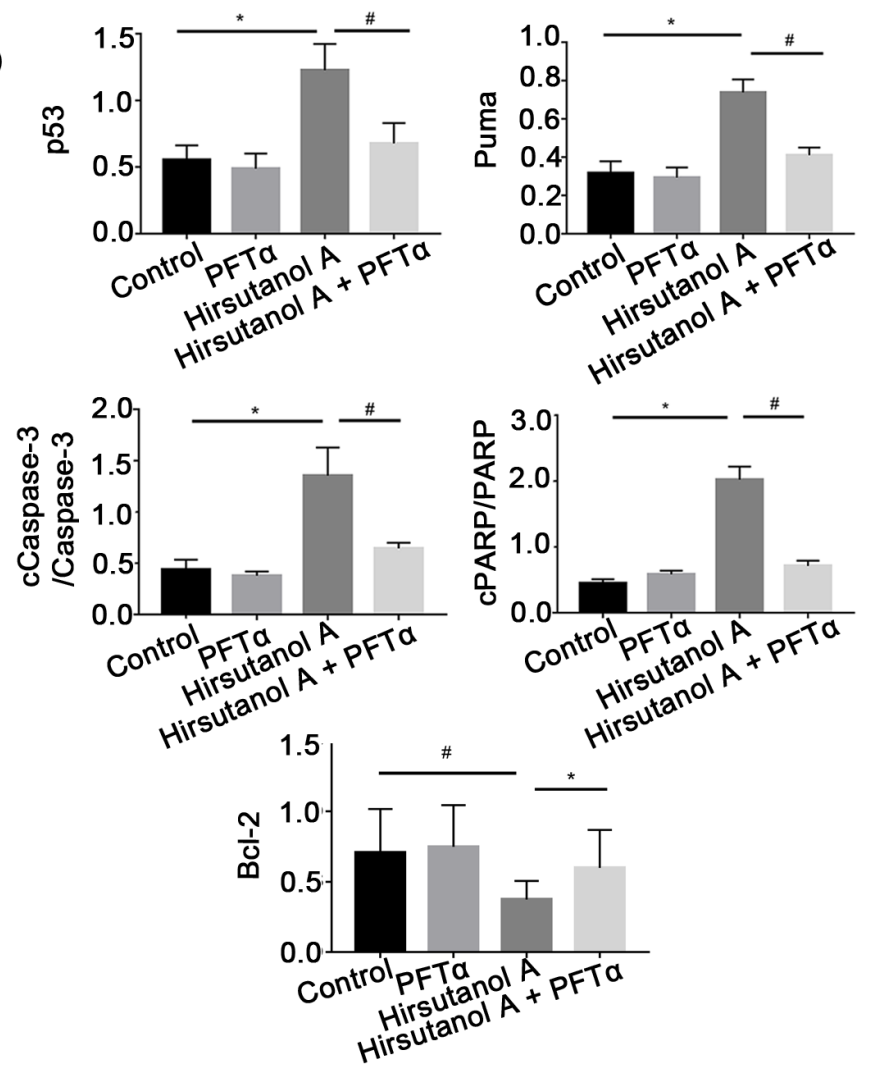

Figure 5. Inhibition of p53 attenuates the effect of hirsutanol A on the apoptosis of Jurkat cells. Jurkat cells were treated with $5 \mu \mathrm{M}$ hirsutanol A, $10 \mu \mathrm{M}$ PFT $\alpha$ or $5 \mu \mathrm{M}$ hirsutanol $\mathrm{A}+10 \mu \mathrm{M}$ PFTa for $48 \mathrm{~h}$. Cells were stained with Annexin V-FITC/propidium iodide and apoptosis was assessed via flow cytometry. After the addition of PFT $\alpha$, the proapoptotic effect of hirsutanol A on Jurkat cells was significantly reduced. (A) Representative dot plots of the flow cytometric analysis of apoptosis. (B) Fractions of apoptotic cells were quantified. (C) Western blot analysis of apoptosis-associated proteins. (D) Semi-quantification of p53, Puma, cCaspase-3 and cPARP protein expression levels. ${ }^{*} \mathrm{P}<0.05 .{ }^{~} \mathrm{P}<0.05$. Data are presented as the mean \pm standard deviation of three independent experiments. c, cleaved; PARP, cleaved poly(ADP-ribose) polymerase; Puma, p53 upregulated modulator of apoptosis; PFT $\alpha$, pifithrin- $\alpha$.

Consistent with the aforementioned results of hirsutanol A inducing apoptosis, compared with the control group, the expression levels of cCaspase-3 and cPARP, well-known apoptotic markers (25), increased significantly following hirsutanol A treatment in a dose-dependent manner (Fig. 4E and F). Furthermore, the expression levels of Puma were significantly increased, whereas the expression of Bcl-2 was significantly decreased after hirsutanol A treatment compared with the control group. As hypothesized, compared with the control group, the expression of p53 in Jurkat cells increased significantly after hirsutanol A treatment in a concentration-dependent manner. 


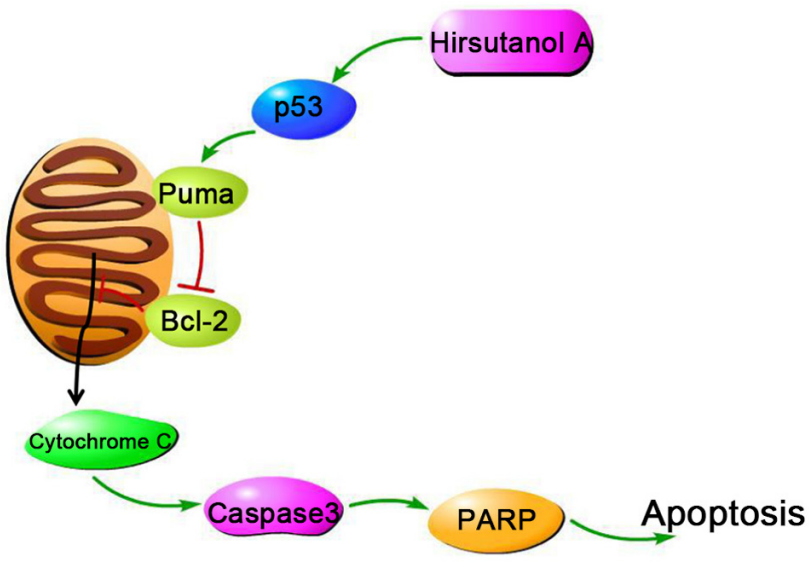

Figure 6. Hirsutanol A inhibits Jurkat cell viability via p53-dependent induction of apoptosis. PARP, cleaved poly(ADP-ribose) polymerase; Puma, p53 upregulated modulator of apoptosis.

Hirsutanol A induces the apoptosis of Jurkat cells via the p53 pathway. As $\mathrm{p} 53$ is one of the master regulators of cell proliferation and cell death (26), whether the induction of apoptosis of Jurkat cells by hirsutanol A was dependent on p53 was assessed. For this, Jurkat cells were treated with the p53 inhibitor PFT $\alpha$ in combination with hirsutanol A. As presented in Fig. 5, apoptosis induced by hirsutanol A was significantly inhibited from $48.92 \pm 0.83$ to $19.24 \pm 0.46 \%$ by PFT $\alpha$. Consistently, the expression levels of proapoptotic proteins (p53, Puma, cCaspase-3 and cPARP) were significantly decreased in the group treated with hirsutanol A + PFT $\alpha$ compared with those in the group treated with hirsutanol A alone, whereas the expression of the antiapoptotic protein Bcl-2 was significantly upregulated (Fig. 5). Collectively, the present results indicated that hirsutanol A inhibited the proliferation of Jurkat cells by inducing cell cycle arrest and p53-dependent apoptosis.

\section{Discussion}

At present, chemotherapy remains the major treatment strategy for T-ALL, which has substantially improved the 5-year survival rate of childhood leukemia (27). However, side effects and cancer cell resistance limit the benefits of chemotherapeutic drugs in current clinical use. Marine organisms live in a special environment of low oxygen, high pressure and high salt, and their metabolites may have clinically relevant biological activities (28). Therefore, the search for efficient and low-toxicity natural medicines from the ocean has attracted increasing interest. Hirsutanol A is a sesquiterpenoid compound extracted from marine organisms and its antitumor activity is widely recognized $(29,30)$. At present, studies into the antitumor activity of hirsutanol A are limited to solid tumors, including liver and nasopharyngeal cancer $(29,31)$. To the best of our knowledge, the present study was the first to explore its inhibitory effect on the proliferation of leukemia cells, a type of blood cancer cell.

In the present study, to the best of our knowledge, it was observed for the first time in vitro that hirsutanol $\mathrm{A}$ inhibited the viability of Jurkat cells, displaying an $\mathrm{IC}_{50}$ value of $5.16 \mu \mathrm{M}$ at $48 \mathrm{~h}$. The CCK-8 assay of Jurkat cells exposed to hirsutanol $\mathrm{A}$ at different concentrations or incubation times revealed that the compound markedly inhibited the viability of Jurkat cells compared with the control group. The present results indicated that hirsutanol A may serve as a candidate drug for the treatment of T-ALL. However, prior to its clinical application, further research is required, including the assessment of the in vitro activities of hirsutanol A in more T-ALL cell lines and evaluation in animal models of T-ALL in vivo, as well as optimization of hirsutanol A to achieve the strongest possible anticancer activity.

Puma is a powerful proapoptotic protein that is able to inhibit the expression of the antiapoptotic protein Bcl-2 (32). If the balance between proapoptotic factors and antiapoptotic factors is altered, the permeability of the mitochondrial membrane increases and cytochrome $\mathrm{c}$ is released into the cytoplasm, thus activating the caspase cascade, which results in caspase-mediated breakdown of the mitochondrial membrane (33-35). Puma is transcriptionally activated by p53 $(36,37)$. To investigate the specific mechanism underlying hirsutanol A-mediated inhibition of Jurkat cell activity, the expression levels of the apoptosis-associated proteins Puma and Bcl-2, as well as the intracellular apoptosis indicator protein cCaspase-3 and its downstream protein cPARP were detected. The results indicated that, compared with the control group, hirsutanol A significantly reduced the expression of the antiapoptotic protein Bcl-2 in Jurkat cells, but significantly increased the expression of the other three proapoptotic proteins, which indicated that hirsutanol A induced the apoptosis of Jurkat cells. This was consistent with another study reporting that hirsutanol A induced apoptosis of human colon cancer SW620 cells and human breast cancer MDA-MB-231 cells (30). At the same time, flow cytometric analysis suggested that hirsutanol A led to cell cycle arrest of Jurkat cells in the $\mathrm{G}_{2}$ phase. Therefore, it was hypothesized that hirsutanol A inhibited the proliferation of Jurkat cells by promoting their apoptosis and blocking the cell cycle.

The present results indicated that the p53 pathway may serve a major role in the inhibition of Jurkat cell proliferation by hirsutanol A. As a transcription factor, p53 regulates a variety of genes involved in apoptosis, the cell cycle, DNA repair and senescence $(38,39)$. p53 induces apoptosis through a number of key proteins that regulate apoptosis signaling and execution, including death receptors (Fas cell surface death receptor 4 and 5), proapoptotic proteins (Puma, NADPH oxidase activator and $\mathrm{Bax}$ ) and apoptotic executioners (Caspase-6, apoptotic peptidase activating factor 1 and Bcl2-interacting protein 3 like) $(40,41)$. Therefore, drugs that induce apoptosis and cell cycle arrest by activating p53 are promising for the treatment of tumors. In the present study, the expression of p53 protein was significantly increased in Jurkat cells treated with hirsutanol A compared with the control group. However, after the addition of p53 inhibitor PFT $\alpha$, the apoptosis-inducing effect of hirsutanol A on Jurkat cells was significantly attenuated. At the same time, following PFT $\alpha$ treatment of hirsutanol A-treated cells, the expression of p53 protein was significantly decreased and the expression trend of apoptosis-associated proteins (Puma and $\mathrm{Bcl}-2$ ) and apoptosis indicators (cCaspase-3 and cPARP) downstream of p53 was significantly reversed. These results suggested that hirsutanol A promoted the apoptosis of Jurkat cells via activation of the p53 pathway, thus inhibiting cell proliferation. However, 
the specific mechanisms underlying hirsutanol A-mediated activation of p53 require further investigation.

Overall, the present study indicated that hirsutanol A inhibited the viability of T-ALL Jurkat cells. It was further demonstrated that the inhibitory effect of hirsutanol A was due to the induction of apoptosis and cell cycle arrest. It is proposed that hirsutanol A induced the apoptosis of Jurkat cells through the p53/Puma/Bcl-2/cCaspase-3 pathway (Fig. 6). However, it is undeniable that there are still some limitations in the present study. For example, only one type of T-ALL cells was used and no animal experiments were conducted. Evaluation of the in vivo anticancer activities, structure-activity relationship and direct targets of hirsutanol A will be the focus of further research. In conclusion, the present study demonstrated that hirsutanol A inhibited Jurkat cell viability through cell cycle arrest and p53-dependent induction of apoptosis, rendering it a promising lead compound for the treatment of T-ALL.

\section{Acknowledgements}

Not applicable.

\section{Funding}

This study was funded by the Science and Technology Project of Health Commission of Sichuan (grant no. 19PJ288), the Basic Application Research of Sichuan Science and Technology Department (grant no. 2019YJ0690), the Key R\&D projects of Sichuan Science and Technology Department (grant no. 2019YFS0531) and the Science and Technology Development Fund, Macau SAR (grant no. 0013/2019/A1).

\section{Availability of data and materials}

The datasets used and/or analyzed during the current study are available from the corresponding author on reasonable request.

\section{Authors' contributions}

WLi and WM designed the study. FZ performed the CCK-8 assay, Hoechst staining, mitochondrial membrane potential detection, western blot analysis and manuscript writing. YY and DR conducted the other functional experiments. FZ and SL collected and analyzed the data. XQ and WLa performed the statistical analysis. JL performed western blot analysis and edited the manuscript. YZ analyzed of data and searched the literature. FZ, WM and WLi confirm the authenticity of all the raw data. All authors read and approved the final manuscript.

\section{Ethics approval and consent to participate}

Not applicable.

\section{Patient consent for publication}

Not applicable.

\section{Competing interests}

The authors declare that they have no competing interests.

\section{References}

1. Gao J and Liu WJ: Prognostic value of the response to prednisone for children with acute lymphoblastic leukemia: A meta-analysis. Eur Rev Med Pharmacol Sci 22: 7858-7866, 2018.

2. Terwilliger T and Abdul-Hay M: Acute lymphoblastic leukemia: A comprehensive review and 2017 update. Blood Cancer J 7: e577, 2017.

3. Papadantonakis $\mathrm{N}$ and Advani AS: Recent advances and novel treatment paradigms in acute lymphocytic leukemia. Ther Adv Hematol 7: 252-269, 2016.

4. Matloub Y, Stork L, Asselin B, Hunger SP, Borowitz M, Jones T, Bostrom B, Gastier-Foster JM, Heerema NA, Carroll A, et al: Outcome of children with standard-risk T-lineage acute lymphoblastic leukemia-comparison among different treatment strategies. Pediatr Blood Cancer 63: 255-261, 2016.

5. Qin X, Zhang MY and Liu WJ: Application of minimal residual disease monitoring in pediatric patients with acute lymphoblastic leukemia. Eur Rev Med Pharmacol Sci 22: 6885-6895, 2018.

6. Wang M, Wen J, Guo Y, Shen Y, An X, Hu Y and Xiao J: Clinical characterization and prognosis of $\mathrm{T}$ cell acute lymphoblastic leukemia with high CRLF2 gene expression in Children. PLoS One 14: e0224652, 2019.

7. Takahashi H, Kajiwara R, Kato M, Hasegawa D, Tomizawa D, Noguchi Y, Koike K, Toyama D, Yabe H, Kajiwara M, et al: Treatment outcome of children with acute lymphoblastic leukemia: The Tokyo Children's Cancer Study Group (TCCSG) Study L04-16. Int J Hematol 108: 98-108, 2018.

8. Li Y, Buijs-Gladdines JG, Canté-Barrett K, Stubbs AP, Vroegindeweij EM, Smits WK, van Marion R, Dinjens WN, Horstmann M, Kuiper RP, et al: IL-7 receptor mutations and steroid resistance in pediatric $\mathrm{T}$ cell acute lymphoblastic leukemia: A genome sequencing study. PLoS Med 13: e1002200, 2016.

9. Raetz EA and Teachey DT: T-cell acute lymphoblastic leukemia. Hematology Am Soc Hematol Educ Program 2016: 580-588, 2016.

10. Punzo F, Manzo I, Tortora C, Pota E, Angelo V, Bellini G, Di Paola A, Verace F, Casale F and Rossi F: Effects of CB2 and TRPV1 receptors' stimulation in pediatric acute T-lymphoblastic leukemia. Oncotarget 9: 21244-21258, 2018.

11. Tosello V and Ferrando A: The NOTCH signaling pathway: Role in the pathogenesis of T-cell acute lymphoblastic leukemia and implication for therapy. Ther Adv Hematol 4: 199-210, 2013.

12. Juliusson G and Hough R: Leukemia. Prog Tumor Res 43: 87-100, 2016.

13. Tan SH, Bertulfo FC and Sanda T: Leukemia-initiating cells in T-cell acute lymphoblastic leukemia. Front Oncol 7: 218, 2017.

14. Rose-Inman H and Kuehl D: Acute leukemia. Hematol Oncol Clin North Am 31: 1011-1028, 2017.

15. Kuhlen M, Klusmann JH and Hoell JI: Molecular approaches to treating pediatric leukemias. Front Pediatr 7: 368, 2019.

16. Wang Y, Chen $\mathrm{H}$ and Chen J: The consensus on the monitoring, treatment, and prevention of leukemia relapse after allogeneic hematopoietic stem cell transplantation in China. Cancer Lett 438: 63-75, 2018.

17. Peters C, Cornish JM, Parikh SH and Kurtzberg J: Stem cell source and outcome after hematopoietic stem cell transplantation (HSCT) in children and adolescents with acute leukemia. Pediatr Clin North Am 57: 27-46, 2010.

18. Wang GYS, Abrell LM, Avelar A, Borgeson BM and Crews P: New hirsutane based sesquiterpenes from salt water cultures of a marine sponge-derived fungus and the terrestrial fungus Coriolus consors. Tetrahedron 26: 7335-7342, 1998.

19. Li HJ, Lan WJ, Lam CK, Yang F and Zhu XF: Hirsutane sesquiterpenoids from the marine-derived fungus Chondrostereum sp. Chem Biodivers 8: 317-324, 2011.

20. Yang F, Chen WD, Deng R, Li DD, Wu KW, Feng GK, Li HJ and Zhu XF: Hirsutanol A induces apoptosis and autophagy via reactive oxygen species accumulation in breast cancer MCF-7 cells. J Pharmacol Sci 119: 214-220, 2012.

21. Wenzel ES and Singh ATK: Cell-cycle checkpoints and aneuploidy on the path to cancer. In Vivo 32: 1-5, 2018.

22. Wang Y, Zhong J, Bai J, Tong R, An F, Jiao P, He L, Zeng D, Long E, Yan J, et al: The application of natural products in cancer therapy by targeting apoptosis pathways. Curr Drug Metab 19: 739-749, 2018.

23. Green DR and Reed JC: Mitochondria and apoptosis. Science 281: 1309-1312, 1998. 
24. Sinha K, Das J, Pal PB and Sil PC: Oxidative stress: The mitochondria-dependent and mitochondria-independent pathways of apoptosis. Arch Toxicol 87: 1157-1180, 2013.

25. Julien O and Wells JA: Caspases and their substrates.Cell Death Differ 24: 1380-1389, 2017.

26. Ranjan A and Iwakuma T: Non-canonical cell death induced by p53. Int J Mol Sci 17: 2068, 2016.

27. Abdelmabood S, Fouda AE, BoujettifF and Mansour A: Treatment outcomes of children with acute lymphoblastic leukemia in a middle-income developing country: High mortalities, early relapses, and poor survival. J Pediatr (Rio J) 96: 108-116, 2020.

28. Khalifa SAM, Elias N, Farag MA, Chen L, Saeed A, Hegazy MF, Moustafa MS, Abd El-Wahed A, Al-Mousawi SM, Musharraf SG, et al: Marine natural products: A source of novel anticancer drugs. Mar Drugs 17: 491, 2019.

29. Yang F, Gao YH, Wu KW, Deng R, Li DD, Wei ZX, Jiang S, Wu XQ, Feng GK, Li HJ and Zhu XF: A novel sesquiterpene Hirsutanol A induces autophagical cell death in human hepatocellular carcinoma cells by increasing reactive oxygen species. Chin J Cancer 29: 655-660, 2010.

30. Yang F, Chen WD, Deng R, Zhang H, Tang J, Wu KW, Li DD Feng GK, Lan WJ, Li HJ and Zhu XF: Hirsutanol A, a novel sesquiterpene compound from fungus Chondrostereum sp. induces apoptosis and inhibits tumor growth through mitochondrial-independent ROS production: Hirsutanol A inhibits tumor growth through ROS production. J Transl Med 11: 32, 2013.

31. Li HJ, Jiang WH, Liang WL, Huang JX, Mo YF, Ding YQ, Lam CK, Qian XJ, Zhu XF and Lan WJ: Induced marine fungus Chondrostereum sp. as a means of producing new sesquiterpenoids chondrosterins I and $\mathrm{J}$ by using glycerol as the carbon source. Mar Drugs 12: 167-175, 2014.

32. Correia C, Lee SH, Meng XW, Vincelette ND, Knorr KL, Ding H, Nowakowski GS, Dai H and Kaufmann SH: Emerging understanding of Bcl-2 biology: Implications for neoplastic progression and treatment. Biochim Biophys Acta 1853: 1658-1671, 2015.
33. Porter AG and Jänicke RU: Emerging roles of caspase-3 in apoptosis. Cell Death Differ 6: 99-104, 1999.

34. Wang Y, Liu C, Wang J, Zhang Y and Chen L: Iodine-131 induces apoptosis in human cardiac muscle cells through the $\mathrm{p} 53 / \mathrm{Bax} / \mathrm{caspase}-3$ and PIDD/caspase-2/t-BID/cytochrome c/caspase-3 signaling pathway. Oncol Rep 38: 1579-1586, 2017.

35. Burke PJ: Mitochondria, bioenergetics and apoptosis in cancer. Trends Cancer 3: 857-870, 2017.

36. Tichy A, Marek J, Havelek R, Pejchal J, Seifrtova M, Zarybnicka L, Filipova A, Rezacova M and Sinkorova Z: New light on an old friend: Targeting PUMA in radioprotection and therapy of cardiovascular and neurodegenerative diseases. Curr Drug Targets 19: 1943-1957, 2018.

37. Vávrová $\mathbf{J}$ and Rezáčová M: Importance of proapoptotic protein PUMA in cell radioresistance. Folia Biol (Praha) 60: 53-56, 2014.

38. Hickman ES, Moroni MC and Helin K: The role of p53 and pRB in apoptosis and cancer. Curr Opin Genet Dev 12: 60-66, 2002.

39. Brázda V and Fojta M: The rich world of p53 DNA binding targets: The role of DNA structure. Int J Mol Sci 20: 5605, 2019.

40. Riley T, Sontag E, Chen P and Levine A: Transcriptional control of human p53-regulated genes. Nat Rev Mol Cell Biol 9: 402-412, 2008.

41. Matt S and Hofmann TG: The DNA damage-induced cell death response: A roadmap to kill cancer cells. Cell Mol Life Sci 73: 2829-2850, 2016.

This work is licensed under a Creative Commons Attribution-NonCommercial-NoDerivatives 4.0 International (CC BY-NC-ND 4.0) License. 